\title{
THE ADMINISTRATIVE PROCEDURE ACT: A STUDY IN OVERESTIMATION
}

\author{
REGINALD PARKER†
}

The Administrative Procedure Act," whose full title is "An Act to improve the administration of justice by prescribing fair administrative procedure," has been presented to the public as "a strongly marked, long sought, and widely heralded advance in democratic government" that despite its brevity "is a comprehensive charter of private liberty and a solemn undertaking of official fairness . . . intended as a guide to him who seeks fair play and equal rights under law. . . . It upholds law and yet lightens the burden of those on whom the law may impinge. It enunciates and emphasizes the tripartite form of our government and brings into relief the ever essential declaration that this is government of law rather than of men." These are the words of Senator McCarran in his foreword to his edition of the legislative history of the Act. ${ }^{2}$ Combining the role of author with that of principal panegyrist of the APA, the Senator four years later hailed his law as "the most important statute affecting the administration of justice in the federal field since the passage of the Judiciary Act of 1789."3 Words like these are so obviously exaggerated that no refutation is necessary. Even the comparatively moderate reference to the Judiciary Act is clearly out of place in view of the fact that the Judiciary Act created the federal judiciary out of a vacuum, whereas the APA neither created nor substantially altered a single government agency. ${ }^{4}$ A inore temperate investigation reveals that the Act's chief merit lies in the fact that it has refrained from any telling innovation.

The history of the Administrative Procedure Act ${ }^{5}$ goes back to the year 1936, when the President's Committee on Administrative Management was

$\dagger$ Visiting Professor of Law, University of Arkansas. This article is the substance of a chapter of the author's forthcoming book, Administrative Law: A TExT, scheduled by The Bobbs-Merrill Co. for the fall of 1951.

1. 60 STAT. 237 (1946), 5 U. S. C. A. $\$ \S 1001-1011$ (Supp. 1950).

2. Sen. Doc. No. 248, 79th Cong., 2d Sess. iii(1946) (hereinafter cited as SEN. Doc. No. 248).

3. McCarran, Three Years of the Federal Adninistrative Procedure Act, 38 Geo. L. J. 574 (1950); Vanderbilt, Foreword; The Federal Adninistrative Procedure ACT AND the Administratrve Agencies iv (Warren ed. 1947); Sen. Doc. No. 248, at 298, 327; Note 32, A. B. A. J. 377 (1946).

4. See the balanced account in Hart, AN Introduction to Administrative Law, 624-36 (1950); Note, 56 Yare L. J. 670 (1947). And see also Nathanson, Some Comments on the Administrative Procedure Act, 41 ILt. L. Rev. 368 (1946).

5. See Sen. Doc. No. 248; Atty. Gen. Man. Ad. Proc. Act S (1947); CCH, A Handbook of Law and Procedure Before Federal Agencies 135-226 (1948); Vanderbilt, Legislative Background of the Federal Administrative Procedure Act in THE Federal Adninistrative Procedure Act and the Admintstrative Agencies 1-15 (Warren ed. 1947). And see the narration of the legislative history in the Wong case cited note 35 
created by the late President Roosevelt. This Committee issued numerous studies and a report, which were transmitted by the President to Congress in 1937. ${ }^{6}$ The report recommended, among other things, a complete separation of the legislative from the judicial functions in every agency exercising both. In 1938 the Senate Judiciary Committee held hearings on a proposal for the establishment of an administrative court.? These ideas, however, proved too radical a departure from the customary American legal standards and were later abandoned. The year 1939 saw the Walter-Logan bill, ${ }^{8}$ which attempted to reach and control the administrative process at its source. It was-or rather tried to be-a comprehensive reform of the quasi-legislative and quasi-judicial procedures. The bill was vetoed by the President, chiefly because he had meanwhile directed the appointment of another committee for further studies and recommendations." In 1941 this committee issued its "Final Report of Attorney-General's Committee on Administrative Procedure,"10 a document of great importance for the understanding of administrative-legal problems. ${ }^{11}$ The Committee also issued 27 separate studies of 33 different administrative agencies. $^{12}$

The Final Report and the individual studies are the overture to the present law. As a result of them, the so-called majority and minority bills were introduced in the Senate, along with revised versions of other bills. ${ }^{13}$ Extensive hearings were held before a subcommittee of the Senate Judiciary Committee early in 1941.14 The war interrupted. New bills were introduced in June 1944 and thereafter, ${ }^{15}$ and eventually in June 1945 a committee print was issued comparing the text of the final bill ${ }^{16}$ with tentative revisions. ${ }^{17}$ Hearings were held by the Judiciary Committee of the House of Representatives. ${ }^{18}$

infra. For still earlier proposals see SEN. Doc. No. 248, at 63, 188; Vanderbilt, supra, at 10 .

6. The Presioent's Comautree on Administrative Management, Report of the Commitree With Studies of Administrative Management in the Federal GovernMIENT (1937).

7. S. 3676, 75th Cong., 3d SEss. (1938).

8. Sen. Rep. No. 442, 76th Cong., 1st Sess. (1939) ; H. R. Rep. No. 1149, 76th Cong., 1st Sess. (1939); Sen. Doc. No. 145, 76th Cong., 3d Sess. (1940). See also Sen. Doc. No. 248 , at $243-5$.

9. H. R. Doc. No. 986, 76th Cong., 3d Sess. (1940).

10. Sen. Doc. No. 8, 77th Cong., 1st Sess. (1941).

11. A deficiency, however, is the lack of an index.

12. Sen. Doc. No. 186, 76th Cong., 3d Sess. (1940) ; Sen. Doc. No. 10, 77th Cong.,

1st Sess. (1941). And see Sen. Doc. No. 248 at 68, 245.

13. S. $674,675,918,77$ th Cong., 1st Sess. (1941).

14. Hearings before Committee on the Judiciary on S. 674, 675 and 918, 77th Cong., 1st Sess. (1941).

15. Sen. Doc. No. 248 , at 63-6, 248.

16. This was the McCarran-Sumners bill that is the basis of the present Act. S. 7 and

H. R. 1203, 79th Cong., 1st Sess. (1945).

17. Sen. Doc. No. 248, at 11-44.

18. Id. at 45-183. 
In October 1945 the Attorney-General submitted a letter and memorandum setting forth the understanding of the Department of Justice as to the meaning and purpose of the various provisions of the revised bill. ${ }^{10}$ In November 1945 and May 1946, the judiciary committees of both Houses of Congress unanimously reported the bill. The reports consist of brief resumés of the legislative history, a general statement of the committee's approach, comparisons of the bill and its forerunners with the Final Report referred to above, ${ }^{20}$ diagrams, analyses of the individual provisions, and general comments. ${ }^{21}$ After further changes of the bill in the judiciary committees of both Houses, the bill was debated and amended in the Senate on March 12, and debated and again amended in the House on May 24, 1946. On May 27 the Senate concurred in the House changes. The bill was signed by the President on June 11, 1946.22 It became effective three months later, i.e., on September 11, 1946. ${ }^{23}$

Like any other statute, an analysis of the Act presents us essentially with two questions: What was the purpose of the Act, and what did it accomplish?

The basic purpose of the APA was obviously the wish to bring about, somehow, a curb of the administrative branch of our government-to see to it "that the governors shall be governed and the regulators shall be regulated."24 Its passage in part at least was due to the deep yearning of the traditional lawyer "for the comparatively simple life of yesteryear" 25 and his desire to put brakes on any new development in the law that disturbed his accustomed way of doing business. ${ }^{2 B}$ The main protagonist of this yearning was the American Bar Association.27 Its efforts met with opposition from administrative agencies and their lawyers as well as from administrative theoreticians. ${ }^{28}$ And

19. Id. at 406-14; Atry. Gen. Man. Ad. Proc. Act 123-39 (1947).

20. See Note 10 supra.

21. SEN. Doc. No. 248, at 185-231, 233-90.

22. 92 Cong. REc. 2148-67, 5645-63, 5745, 5788-91, 5811, 5954, 6073, 6706 (March 12, May 24, 25, 27, 29, 31, June 12, 1946) ; SEN. Doc. No. 248, at 293-406.

23. APA §12. The effect of certain of its provisions was deferred. As to the Act's applicability to proceedings initiated prior to its effective date, see Oklahoma v. Civil Service Commission, 330 U. S. 127, 138 (1947), and Justice Frankfurter's concurring opinion, $i d$. at 147.

24: SEN. Doc. No. 248, at 244.

25. Id. at 243 .

26. It is generally agreed that the opposition of professional real property lawyers is a main reason why the Torrens system of land recordation has been so unsuccessful in this country. Professor Paul Koschaker, in his recent classic, EUROPA UND DAS ROEMISCHE RECHT (1947), makes the point that the chief reason for the rejection of Roman law in England was the resistance of the legal profession, which saw its traditional ways disturbed. See this writer's review in 42 Axr. J. INTL. L. 975 (1948).

27. See SEN. Doc. No. 248, at 63-6, and passin; Blachly, Critique of the Federal Administrative Act in The Federal Administratrve Procedure Act and the Administratrve AgENCIEs 30 (Warren ed. 1947); Gwynne, Architecture of the New Administrative Procedure Act, 32 A. B. A. J. 550 (1946).

28. See supra note 14; Sen. Doc. No. 248, at 247-48, 392; Blachly \& Oatman, Sabotage of the Administrative Process, 6 Puв. AdMIN. REv. 213 (1946). And see Blachly, supra note 27. 
while the deliberations went on, the courts gained in understanding of administrative-legal problems. ${ }^{29}$ The result of these conflicting currents was the present Act, which was conceded to be somewhat less far-reaching than its first proponents wanted. ${ }^{30}$ Some opponents greeted the new law with the same vehement antipathy with which they had opposed the prior bills. ${ }^{31}$ Other critics were more or less satisfied with the comparatively small innovations the Act brought about. ${ }^{32}$ The Act thus had lukewarm as well as hot support. ${ }^{33}$

At the outset it is clear that, despite its title, the Act does not endeavor to regulate the-i.e., every-administrative procedure. The APA is merely directed at rule making and the adjudication of individual cases as well as certain matters ancillary to both. It is probably neither possible nor desirable to regulate the many other administrative functions of the Government, such as the managerial and custodial acts performed by the National Archives or the Public Building Administration, the very important task of preparing the nation's budget, or the activities of the Office of Education. Some proponents of the new law made allusion to the "barnacle growth" of the administrative branch, which supposedly endangers our ship of state and which constitutes a fourth "headless" branch of government. ${ }^{34}$ The legislators have not seen fit to do anything about it. The APA neither reduces the number of administrative agencies, nor prevents their growth, nor changes their powers materially, nor subjects them to the control of either the President or the Congress to a greater extent than heretofore.

Within the limited scope of what the Act is intended to do, its most frequently-named goals ${ }^{35}$ are the codification of administrative procedure ${ }^{36}$ the

29. E.g., Dobson v. Commissioner, 320 U. S. 489 (1943) ; NLRB v. Hearst Publications, Inc., 322 U. S. 111 (1944). Cf. McFarland, Discussion, in The Federal AdMINIstrative Procedure Act and the Administrative Agen(ites 69 (Warren ed. 1947) (Dobson rule has remained unchanged).

30. SEN. Doc. No. 248, at 188-91, 243, 247-9.

31. Blachly, supra note 27; Blachly, The Federal Administrative Procedure Act, 34 GEo. L.J. 407 (1946) ; Blachly \& Oatman, supra note 28. And see also Hart, op. cit. supra note 4 , at $627-8$.

32. See, e. g., note 4 supra.

33. See notes 2 and 3 supra.

34. SEN. Doc. No. 248, at 338.

35. The APA's "legislative history is more conflicting than the text is ambiguous." Wong Yang Sung v. McGrath, 339 U. S. 33, 49 (1950) ; "Congress expressed a mood." Universal Camera Corp. v. NLRB, 340 U. S. 474, 487 (1951). See SEN. Doc. No. 248, at 303-4. Senator McCarran (not a specification of the details of administrative procedure, nor a codification; merely "an outline of minimum basic essentials"); $i d$. at 407, Attorney General Clark (there is nothing inherent in the subject of administrative law "which defies workable codification") ; id. at 298 , Senator McCarran (a "bill of rights for ... Americans whose affairs are controlled or regulated . . . by agencies . . .; a simple and standardized plan of administrative procedure"); $i d$. at 307, Senator McCarran (nothing in the bill that interferes with existing administrative procedure) ; id. at 318-19, Senators McCarran and McKellar ("principal purpose of the bill" as well as its "general underlying purpose" is to afford aggrieved parties judicial review); id. at 347 , Congress- 
achievement of uniformity, standardization, and simplification $;^{37}$ the curbing of administrative excesses $;^{38}$ and the publicizing of administrative acts. ${ }^{30}$ The Act is also supposed to require agencies to base their determination on "something more than "any evidence" "40 to "allow persons who are aggrieved as the result of acts of governmental agencies to appeal to the courts" ; 4 to establish a uniform system of judicial review for "every legal wrong" committed by agencies ;2 and to provide for an "outline of minimum basic essentials" of administrative procedure. ${ }^{43}$ Even a limited analysis of the problems of administrative law shows that the Act is far away from these goals. ${ }^{44}$

The Administrative Procedure Act is anything but a codification either of administrative procedure as such or of those types of rule malking and adjudication to which the Act applies. ${ }^{45}$ A code or similar comprehensive body of law would name the instances when, in adjudicatory proceedings, hearings are required, whereas the APA leaves this supreme question to existing law. ${ }^{40}$ A code would rule in which cases what modes of notice are required, ${ }^{47}$ but the APA merely restates in a general fashion that parties must be informed

man Pittenger (same); $i d$. at 345-7, Congressmen Sabath and Michener (to improve administration of justice by prescribing fair administrative procedure; to see that the people receive justice). Etc.

36. Id. at $298,349,407$.

37. Id. at 243, 379-80. See also Justice Jackson for the Court in Wong Yang Sung v. McGrath, 339 U.S. 33, 41 (1950).

38. SEN. Doc. No. 248, at 243-4, 249, 337-8 (the "barnacle growth" of the executive branch).

39. Id. at $251,304,346,348,353,356-8$.

40. Id. at 321 .

41. Id. at $318-19,347$.

42. Id. at $305,308-10,354,368$.

43. Id. at $303-4$.

44. Savigny wrote in 1814 that the time had to be "ripe" for a codification of lawi.e., that a given branch of law had to be sufficiently advanced to be capable of being restated, or where desirable, remodeled in detail. American administrative law, with its tremendous vagueness, is the perfect example of a branch of law which fails to meet these requirements. See FrIEdrich KARL vON SAvigny, VOM BERUF UNSRER ZEIT fUER Gesetgebung UND Rechtswissenschaft (3d ed. 1840). There exist several English translations. For a good recent evaluation see KosCEAKER, op. cit. supra note 26, at 258-9.

45. For a competent evaluation of the possibilities of an administrative-legal code see the report in Rep. Atr'y. Gen. Conra. Ad. Proc. 191-2 (1941).

46. APA $\$ 5$, first sentence. The legislative language and intent confine the applicability of $\S 5$ to cases where hearing is required by statute. SEN. Doc. No. 248, at 21, 202, 260,359 . But the $W$ ong decision, supra note 35 , broadens this to mean any law, as distinguished from mere custom or a regulation the making of which is not imposed upon the agency by law. This was followed in Riss \& Co. v. United States, $71 \mathrm{~S}$. Ct. 620 (1951).

47. Notice, to comply with due process, may be given by the pertinent statute itself. Lander v. Mercantile Bank, 186 U.S. 458 (1902) ; Pittsburgh, C., Ch. \& St. L. Ry. v. Backus, 154 U.S. 421 (1894). And see Anderson Natl. Bank v. Luckett, 321 U.S. 233 (1944) (notice by publication) ; Bi-Metallic Investment Co. v. State Board of Equalization, 239 U.S. 441 (1915) (class action). 
of time, place and nature of the hearing, ${ }^{48}$ leaving the question of sufficiency again to "the law." In a century or so we might be able to say exactly who is to be a "party" in administrative proceedings, but at the present the APA merely says in so many words that a party is anybody who is entitled (that is, of course, under "the law") to be a party..$^{49}$ Similarly, the problem of who has standing to seek judicial review is inadequately answered by merely saying, anybody "suffering legal wrong" or being "adversely affected or aggrieved" within the meaning of the law. ${ }^{50}$ Perhaps the time will never come when we can spell out the details of these general, vague norms in the same fashion as, say, the hearsay rule. It certainly is not here yet.

The demand for uniformity, standardization and hence simplification has fared not much better. The variance between rules of procedure of the several agencies is probably not as great as many people seemed to have imagined, ${ }^{51}$ but the APA does not lessen it anyway. The issues whether in a given case there must be a hearing and if so, who is entitled to it, and whether it must be oral, etc., are left unanswered.52 The Act does strengthen certain principles such as the separation of functions of judge and advocate or that the one who hears must himself at least recommend a decision.53 But these and other innovations apply only where the Act in general and the hearing provisions in particular apply, and where none of the many exceptions lie. ${ }^{54}$ The law is now not much more uniform in these regards than it was before the APA. Nor has the rule making procedure been standardized. There are now, as ever, a great many types of permissible procedures in rule making: where no part of the Act applies ${ }^{55}$ where only Section 3, dealing with publication of rules, applies; ${ }^{56}$ where the procedure of Section 4 (a) and (b), first sen-

48. APA \$ 5 (a). The requirement of clause (2), whereby the notice must give the "legal authority and jurisdiction" under which the hearing is to be held is a commendable innovation.

49. See the discussion of the term "party" in APA \&2 (b), at notes 112-16 infra.

50. APA $\$ 10$ (a). Dickinson, The Judicial Review Provisions of the Federal Administrative Procedure Act (Section 10), Background and Effect in The Federal Administrative Procedure Act and the Administrative Agencies 546 (Warren ed. 1947), believes that $\S 10$ is an improvement of the law. Many of his views, however, are not embodied within the four corners of the Act and, consequently, have not been followed by the courts or agencies.

51. Blachly, supra note 27. But see SEN. Doc. No. 248, at 243, 348.

52. Cf. the discussion in WJR, The Goodwill Station v. FCC, 174 F. $2 d 226$ (D.C. Cir., 1948), reversed sub. nom. FCC v. WJR, 337 U. S. 265 (1949); Philadelphia Co. v. SEC, infra note 121 .

53. APA $\$ 2$ (a), a somewhat diluted version of the postulate, "the one who decides must hear" of Morgan v. United States, 298 U.S. 468, 481 (1936).

54. APA $\$ 2$ (a), as amended; $\$ 5$, first sentence; $\S 8$ (a), last sentence. And see notes 104-111 infra.

55. I.e., not even $\$ 3$ : functions requiring secrecy or relating solely to internal management. APA $\$ 3$, first sentence.

56. Because the agency is otherwise exempted from the APA under $\$ 2$ (a), as amended. 
tence, would per se apply, but the agency for "good cause" finds its application impracticable $;{ }^{57}$ where the enabling statute requires that the regulation be made only upon the record of a formal hearing; 58 and lastly, where the enabling statute merely demands a "hearing," but does not provide that the regulation must be based upon the record of the hearing. ${ }^{59}$ The principal stride towards standardization is a minor one-the mandate that in dubio the consultative procedure of Sections 4 (a) and (b), first sentence, is to apply.

Where the Act changes rather than restates the law, it naturally curbs administrative agencies to a certain degree. Thus, if none of the exceptions are applicable, an adjudicatory hearing must now be given by an examiner qualified under Section 11 . The rule making process must be conducted so as to give parties interested an opportunity to express their views. And the right of parties to have counsel and to be issued subpoenas is established beyond doubt as far as the Act goes. ${ }^{60}$ To some extent then, administrative law has been changed to favor private parties and limit the freedom with which agencies can act. ${ }^{81}$

These limited changes, however, do not come close to an effective curb of the administrative branch of the Government as such. The governors are now not essentially more governed, nor the regulators regulated, ${ }^{62}$ than before. Administrative agencies flourish as ever and the APA has neither diminished their number nor curtailed their various, heterogenous purposes. Such rules as that of primary jurisdiction, exhaustion of administrative remedies, and substantial evidence, which have strengthened agencies' position so much during the last decades remain untouched. Nor has the Act diminished the force of the most recent judge-made administrative legal doctrine, giving preponderant weight to agency holdings involving both so-called mixed questions and the agency's qualified experience. ${ }^{63}$ Unchanged is the broad power of delegated legislation, at one time so obnoxious to many traditional lawyers. Agencies make rules, pursuant to wide statutory authority, as they see fit

57. APA $\$ 4$ (a), last sentence.

58. $I d$. $\$ 4(\mathrm{~b})$, second sentence.

59. Atr. Gen. Man. Ad. Proc. Act 34-5 (1947) ; Reich, infra note 118, at 501-504. And see Norwegian Nitrogen Products Co. v. United States, 288 U.S. 294 (1933).

60. $\$ 6(a)$ and (c).

61. By using these words, however, I do not mean to join in the somewhat naive language of many that regard agencies as parties to whose "advantage" or "disadvantage" law may be enacted. Rather, they are public authorities, charged with representing the people.

62. See note 24 supra.

63. Justice Douglas, concurring in United States v. Gerlach Live Stock Co., $70 \mathrm{~S}$. Ct. 955, 971, 974 (1950): "This Court has often emphasized that weight is to be given to the interpretation of statute made by the administrative agency." (Citing, inter alia, the Hearst case, supra note 29). And see McFarland's remark, supra note 29. 
and the courts, as a rule, do not interfere. ${ }^{64}$ Nor does the Administrative Procedure Act.

It has been asserted that the Act imposes publicity on administrative agencies. ${ }^{65}$ Actually, however, this was done by the establishment of the Federal Register ten years before the APA, at least as far as regulations are concerned. ${ }^{66}$ The present law, it is true, applies also to orders, which must generally be open to public inspection. Matters of official record must be made available to parties concerned. ${ }^{67}$ This was in conformity with good practice even before the APA, ${ }^{68}$ but of course it is an improvement to have it in the statute book. As to regulations, the Act differs from the Federal Register Act but in two regards. It is retroactive, as far as procedural and organizational regulations are concerned, ${ }^{69}$ and it includes in the material that must be published-though not retroactively- "statements of general policy or interpretation." "70 The agencies throughout the land complied with the former provision by publishing all their rules of procedure and their organization in the Federal Register of September 11, 1946,71 which consisted of nearly 1000 pages fine print. I do not think it was read by many people. ${ }^{22}$ The wisdom of requiring the inclusion of mere interpretations in the Register is subject to doubt. ${ }^{73}$ The sanction on failure to publish a regulation in the Register means, briefly, that it cannot be enforced. Since an interpretation is by its nature not enforced anyway, the provision requiring its publication is meaningless, to be followed or not at will. ${ }^{74}$

64. See, e.g., cases cited, note 130 infra.

65. See note 39 supra.

66. Fed. Reg. Act, 49 Stat. 500 (1935), 44 U.S.C.A. $\$ 301$ (Supp. 1950). For an analysis of the present and past unsatisfactory situation see Newman, Government and Ignorance-Progress Report on Publication of Federal Regulations, 63 HARv. L. Rev. 929 (1950).

67. APA $\S 3(\mathrm{~b}),(\mathrm{c})$. Matters of a confidential nature are excepted.

68. Cf. Rep. Atr'y. Gen. Comm. Ad. Proc. 25, 29-30 (1941).

69. $\S 3(a)(1)$ and (2), applying to rules of procedure and organization that existed at the time when the Act went into effect.

70. $\$ 3(a)(3)$.

71. The statements relating the agencies' organizations have not been included in the Code of Federal Regulations. 1 Code FEd. REgs. $\$ \$ 1.43$, 1.45 (a) (1949); 13 FEd. REG. 5931 (1948); Newman, supra note 66, at 949 (1950); McCarran, supra note 3 , at 577.

72. The "monster edition" of the Federal Register. McCarran, supra note 3, at 576 . "To place information regarding the governmental agencies in the Federal Register is to make it unavailable to most people. ..." Blachley, supra note 27 , at 49 .

73. For a further discussion of the difference between a regulation and an interpretative statement, see notes 117-34 infra.

74. Thus, as is generally known, many Internal Revenue interpretations-often called "rulings," "opinions," etc.--are not published in the Register. Dwan, The Federal Administrative Procedure Act and the Burean of Internal Revenue in THE FEDERAL AdMInIstratrve Procedure Acr and the Administrative Agencies 144-50, 162, 168 (Warren ed. 1947). 
A reader of the legislative history of the Act must get the impression that in the past "any evidence, or a scintilla of evidence, as it is sometimes defined" was considered sufficient for sustaining an administrative decision, and that the APA now does away with this by subjecting to court review decisions that are not based on substantial evidence..$^{75}$ Exactly the opposite is true. ${ }^{76}$ Heralded as a change, this provision is but little more than a codification of the Consolidated Edison case, ${ }^{77}$ where the Supreme Court made it clear that a decision not based on substantial evidence will not be upheld, despite the fact that the pertinent Section 10 (e) of the Wagner Act, under which the case arose, merely provided that the findings of the Board must be upheld if supported "by evidence." 78 In so holding the Court added that "substantial evidence is more than a mere scintilla."70 The process by which this unequivocal statement that a mere scintilla is never sufficient-from which derive all the "scintilla" allusions in subsequent decisons involving administrative law " crept into both Houses of Congress as support for the contrary proposition ${ }^{81}$ is not clear.

If it is true that allowing parties to seek judicial review is "the principal purpose of the bill,"s2 the Act accomplishes very little. Court control, by and

75. See text at note 40 supra. For more congressional remarks see SEN. Doc. No. 248, at 386 (Congressman Russell : "if the proposed provision becomes law"-as it did, $\$ 10$ (e) (5)-then "the law making that scintilla of evidence binding upon the court" will remain as it is). And see note 81 infra.

76. The origin of the "scintilla" phrase is obscure. See Offutt v. World's Columbian Exposition, 175 I11. 472, 476, 51 N.E. 651,652 (1898).

77. Consolidated Edison Co. v. NLRB, 305 U.S. 197, 229 (1938). And see, e.g., NLRB v. Montgomery Ward \& Co., 133 F. 2d 676, 685 (9th Cir. 1943) ; Matter of Stork Restaurant, Inc. v. Boland, 282 N.Y. 256, 273-4, 26 N.E. 2d 247, 255 (1940). See also note 81 infra.

78. NLRA $\$ 10$ (e), as amended by the Taft-Hartley Act, now says "substantial evidence." The extent, if any, to which the Universal Camera case, supra note 35, has wrought a true change of the law is not yet visible. See also HARr, op. cit. supra note 4 , at $677-8$.

79. Consolidated Edison Co. v. NLRB, supra note 77, at 229.

80. E.g., cases in, note 77 supra, or the Bridges case, infra note 81.

81. The above-quoted language was used in the Senate. See note 40 stipra. In the House, Congressman Walter seems to have entertained a similar opinion: "Under this section the function of the courts is not merely to search the record to see whether it is barren of any evidence ... or supports the agency by a scintilla or by mere hearsay, rumor, suspicion, speculation, and inference-cf. Edison Co. v. Labor Board (305 U.S. 197, 229-30). Under this bill it will not be sufficient for the Court to find, as the late Chief Justice Stone pointed out within the year, merely that there is some "tenuous support of evidence'-Bridges v. Wixon, (326 U.S. at 178)." SEN. Doc. No. 248, at 370. Actually, however, Chief Justice Stone's dissenting opinion in the Bridges case, 326 U.S. 135, 166 (1945), is clearly intended to remind the Court of the rule "which it has followed for many years" that, when there is "evidence more than a scintilla" to support an agency finding, the courts will uphold it. And see Congressman Russell, supra note 75. Congressional statements like these render questionable the correctness of the repeated assertion that the Act is the product of careful, elaborate studies.

82. See notes 41,42 supra. 
large, existed prior to the Act where it exists now, except perhaps for deportation cases where under the old law only habeas corpus was available. ${ }^{83}$ This relatively small change in the law could have been accomplished by a simple amendment to the Immigration Act. ${ }^{84}$ The new law does no more than restate the wide and vague grounds upon which judicial review may be sought. ${ }^{85}$ It might have brought about a measure of uniformity-really not of administrative but of judicial law-by replacing the various forms of action for judicial review by one petition for judicial review. It did not. It preserves both the existing statutory actions for judicial review (which often simply provide for a petition for review) and in their absence or inadequacy the non-statutory common-law writs. ${ }^{80}$

Of course, it would be an exaggeration to say that the APA is altogether useless. It has brought several clarifications and improvements. The adoption of the substantial evidence rule, for instance, has put to rest many, though not all old arguments. Prior to the Act there existed some holdings that could be cited in favor of the so-called review of the record rule, whereby the review court, without holding a trial de novo, yet reviewed and weighed the evidence upon the record ${ }^{87}$ Apart from trials de novo, which the Act expressly preserves, ${ }^{88}$ the law now is to the effect that courts may not reappraise the evidence that was before the agency. Rather, the review court is bound to accept it if it is substantial. ${ }^{89}$ The establishment of independent trial examiners can be greeted as a step forward, particularly in a governmental system where otherwise the tenure of office of the civil servants is without efficient protec-

83. See the Bridges case, supra note 81. And see Wong Yang Sung v. McGrath, 339 U.S. 33 (1950). A comparison between the two decisions reveals no world-shaking improvement of the deportees' rights.

84. It is not entirely clear how this provision got in anyway. One of the Act's main proponents was Senator McCarran, not otherwise known for friendly sentiments toward prospective deportees. Bills have been introduced to exempt deportation proceedings from the Act. S. 2755 and H. R. 6652, 80th Cong., 2d Sess. (1948) ; H. R. 10, 81st Cong., 1st Sess. $\$ 2$ (1949).

85. APA $\S 10$. And see McFarland's remarks, supra note 29 , which confirm that there is no change in the law of judicial review even in the hotly contested field of "mixed" questions.

86. APA $\S 10$ (b) ; SEN. Doc. No. 248, at 325-6. For a comprehensive study see Dickinson, supra note 89.

87. See St. Joseph Stock Yards Co. v. United States, 298 U.S. 38 (1935).

88. APA $\$ \$ 5(1), 10$ (e) (6). But the Act, rather typically, fails to explain when a trial is de novo. Cf. Parker, Administrative Law in Arkansas, 4 ARk. L. Rev. 107, 125-7 (1950).

89. United States v. United States Smelting, Refining \& Mining Co., 339 U.S. 186, 193 (1950); NLRB v. Crompton-Highland Mills, Inc., 337 U.S. 217, 220-21 (1949); United States ex rel. Lindeman v. Watkins, 73 F. Supp. 216 (S.D.N.Y. 1947). CARRow, Baciggound of Administratrve Law $155-7$ (1948). But see Dickinson, The Indicial Review Provision of the Federal Administrative Procedure Act in The Federal Adurnistrative Procedure Act and the Administratnve Agencies 546, 554-62, 578-89 (Warren ed. 1947). But see the Universal Camera case, supra notes $35,78$. 
tion. ${ }^{90}$ No world-shaking effects have resulted from the requirement that regulations ought to be made after giving interested quarters an opportunity for consultation, but this provision also may be considered an improvement. ${ }^{11}$ While the Act can be said to be barely an outline of even a minimum of essentials that are basic, ${ }^{92}$ it does inch forward in that direction. ${ }^{93}$ Lack of space, however, forbids a complete analysis of how much is changed in the eleven sections of the Act, and how much constitutes merely codification of vagueness. Yet, the usefulness and quality of a statute can often be deduced from an examination of its definitions. If clarity exists here, it follows that the law has contributed to the elimination of at least some controversial issues. If, on the other hand, the definition of terms that are frequently used in the statute clarifies nothing, or even perchance increases existing doubts, the statute cannot easily constitute a technical improvement of the law. And as a technical improvement is the essence of a procedural statute, we may confine our further inquiry to Section 2 of the Act, which contains definitions.

Subsection (a). This defines the term "agency," states that statutory delegations of authority remain unchanged, and lists the agencies that are excluded from the operation of the Act.

A. "Agency" is defined as "each authority (whether or not within or subject to review by another agency) of the Government" other than Congress, courts, or the governments of the possessions, territories, or the District of Columbia. This leaves in doubt the principal issues it is designed to clarify:

(1) The definitional scheme is a negative one, depending mainly on saying what an "agency" is not. What one is, is so broadly stated as to breed confusion. For example, the President of the United States, though definitely neither Congress nor a court, does not seem to fall under the APA. This is of major importance to the rule making process. The Chief Executive does not usually

90. Carter v. Forrestal, 175 F. 2d 364, 365 (D. C. Cir. 1949), cert. denied, 338 U.S. 832, (1949) (dismissal from Civil Service will not be judicially reviewed); Groghan v. United States, 89 F. Supp. 1002 (Ct. Cl. 1950), citing many cases; Bailey v. Richardson, 182 F. 2d 46, 58 (D.C. Cir. 1950), aff'd by equally divided court, 19 U.S.L. WEEK 3296 (U.S. May 1, 1951) (dismissal from Civil Service for loyalty reasons without due process valid).

91. Which, however, must not be overrated. Cf. Lansden v. Hart, 168 F. 2d 409 (7th Cir. 1948), cert. denied, 335 U.S. 858 (1948) (approving notice of proposed rulemaking that was given six days prior to, and a hearing thereon after, the publication of the rule). The Fair Labor Standards Act of 1949, in $\$ 7$ (d) (3) (b), authorizes certain regulations concerning profit sharing plans; the statute became law on October 26, 1949, and went into effect January 25, 1950; and only on that day did the Wage and Hour Administrator publish the regulation, stating that the fact that the FLSA went into effect the same day made it necessary to promulgate the regulation with immediate effect, without benefit of pre-publication, consultation, etc. 15 FED. REg. 401 (1950). The Administrator fails to explain why it was necessary to wait until the rule making procedure of APA $\$ 4$ (a), (b) became impracticable.

92. See note 43 supra.

93. Some of its proponents thought that the Act is "not the final answer . . . we will taken another step next year..." SEN. Doc. No. 248, at 338. 
decide individual cases, ${ }^{94}$ and where he does the adjudicatory process would be inapplicable in view of the first sentence of APA Section 5.95 On the other hand, there is nothing in the language of either the Act or its history that would exclude the President's rule making functions from the operation of the Act. In fact, of course, the Executive orders of the President, as his regulations are called, are not made pursuant to Section 4 . The President has never announced in the Federal Register intention to make a regulation; nor has he afforded interested parties an opportunity of expressing their views on the proposed regulation. Moreover, his Executive Orders are covered by the Federal Register Act ${ }^{96}$ and published pursuant to that statute rather than APA Section 3(a) (3). As a result, the President does not publish in the Federal Register his "statements of general policy," as Section 3(a) (3) decrees. ${ }^{.7}$

The example chosen may seem far-fetched. Anyone can infer that the Act is not to apply to the President. But the purpose of statutory definition is to be precise. Any definitional section may raise difficulties in border-line cases. One that does not solve even obvious cases falls far short of its objective.

(2) It has always been clear that a "court" is not an administrative agency. To know this is useful, however, only if you know what a "court" is. The APA fails to define the term. The difference between the two types of governmental, law-applying authorities-courts and agencies-is one of shades rather than absolutes. Legal theory characterizes courts as endowed with "independence," that is, as subject merely to the law and not to the instructions or policies of superior organs. ${ }^{98}$ It is obvious that this distinction cannot be applied here. If it were, much of the APA would be superfluous, for the Act aims particularly at the adjudicatory agencies, such as the NLRB or the FTC, which enjoy the

94. There are some exceptions. E. g., $\$ \$ 801,1006$ of the Civil Aeronautics Act, 52 Stat. 1014 (1938), 49 U.S.C.A. 601, 646 (Supp. 1951); Chicago \& Southern Air Lines v. Waterman S. S. Corp., 333 U. S. 103 (1948), 61 HARv. L. Rev. 1053.

95. In view of the interpretation, however, which the Wong Yang Sung case, supra note 35 , has given APA $\S 5$, the President one day may find himself confronted with the demand that he comply with this section whenever he decides upon a case, see note 94 supra, where "the law" requires a hearing.

96. Federal Register Act § 5, 49 Stat. 501 (1935), 44 U. S. C. 305 (1946). The procedure of publishing Executive Orders is regulated in Exec. Order No. 7298 (1936) and Exec. Order No. 10,006 (1948), 13 Fed. Reg. 5927 (1948), 1 Code Fed. Reg. 1.91-1.97 (1949).

97. It is worth observing, however, that the "monster edition" of the FEDERAI REGISTER of September 11, 1946, does contain a very brief statement of the "organization" of the Executive Office of the President. This might be regarded as a tentative compliance with APA $\$ 3$ (a) (1). As to his "functions," see APA $\$ 3$ (a) (2), however, there is, in lieu of a description, merely the statement that the President has directed that this information "be included in the explanation of the organization and procedures of the respective agencies of the Executive Branch which administer such functions on behalf of the President...."

98. Kelsen, Generaz Theory of Law and State 275 (1945). 
independence that is the theoretical criterion of courts. The line, then, cannot be drawn from legal theory. The term "court" must rather be conceived as meaning "court within the positive law": whatever is statutorily assigned to the judicial branch of government is a "court." This is true not only of the "constitutional" courts, 99 but also of the statutory courts under the Judiciary Code, ${ }^{100}$ such as the courts of appeal, the Court of Claims, the Court of Customs and Patent Appeals, and the Customs Court. ${ }^{101}$ On the other hand, agencies both exercising judicial (often called quasi-judicial) functions and enjoying judicial independence, but not designated as falling within the purview of the judiciary, are probably not "courts" within Section 2 (a). Into this category falls the Tax Court, which, despite its name, ${ }^{102}$ is not organized under the Judicial Code and is statutorily defined as "an independent agency in the Executive Branch of the Government.".'103

B. Subsection (a), with its mass of amendments, includes a formidable list of agencies that are excluded from the operation of the Act (except as to Section 3 ). Some of the exempted agencies may rightly be regarded as organically not fitting into the pattern of the Act. Disputes where the parties' agents take part, as judges, in making the decision, ${ }^{104}$ are akin to arbitration proceedings, which traditionally are not circumscribed by procedural rules. The exclusion of the military functions ${ }^{105}$ can be ascribed to the fact that nowadays we do not consider acts of, or pertaining to, the armed forces as coming under administrative law, ${ }^{100}$ and that military necessity and expediency may be guided by the same

99. As established by direct mandate of U. S. Const. Art. III. For the distinction between constitutional and legislative courts, see Ex parte Bakelite Corp., 279 U. S. 438 (1929) ; Federal Radio Commission v. General Electric Co., 281 U. S. 464 (1930); Federal Radio Commission v. Helson Bros. Bond and Mortgage Co., 289 U. S. 266 (1933) ; O'Donoghue v. United States 289 U. S. 516 (1933); Williams v. United States, 289 U. S. 553 (1933).

100. 28 U. S. C.

101. Id. $\$ \S 41-255$. And see Schwartz, infra note 103.

102. Its forerunner was the Board of Tax Appeals. See note 103 infra.

103. Internal Revenue Code $\S 1100$, as amended by $\S 504$ of the Revenue Act of 1942, 56 STat. 798 (1942), 26 U. S. C. $\$ 1100$ (1946), Lincoln Electric Co. v. Comm'r., 162 F. 2d 379, (6th Cir. 1947) ; Gillette's Estate v. Comm'r., 182 F. 2d 1010, 1013 (9th Cir. 1950). And see Cohen v. Comm'r., 176 F. 2d 394, 396 (10th Cir. 1949). Contra: Anderson v. Comm'r., 164 F. $2 d$ 870, 874 (7th Cir. 1947) ; Atty. Gen. in SEN. Doc. No. 248, at 225, 408; Atry. Gen. Man. at 10 . And see Schwartz, Administrative Terminology and the Administrative Procedure Act, 48 MrcH. L. REv. 57, 61-2 (1949). For a similar problem under state law see Mulhearn v. Federal Shipbuilding \& Drydock Co., 2 N. J. 356 (Sup. Ct.), 66 A. $2 d 726$ (1949).

104. APA $\S 2(a)(1)$.

105. Id. $\$ 2(\mathrm{a})(2)$, (3), and (4).

106. Historically, the military and foreign affairs function of the chief of state were the starting point, so to speak, for Locke's and Montesquien's separation of powers doctrines. See Parker, Separation of Powers Revisited: Its Meaning to Administrative Laze, 49 Mrсн. L. REv. 1010 (1951). 
rules of procedure that apply to the civil functions of the Government. The exclusion of the remaining agencies and their procedures, however, is based on somewhat less convincing grounds. Despite the fact that it was the war agencies which gave rise to the most outspoken complaints and criticism, ${ }^{107}$ they are excluded on the ground that they are merely temporary whereas the Act was intended to be permanent legislation; and that, in any event, "those agencies are erected under orders and statutes that provide a special method of review of their decision."10s Neither argument is convincing. For one thing, the premise of temporariness appears factually untrue. ${ }^{109}$ For another, the policy is unclear. If the APA constitutes an improvement, why not apply it to temporary agencies? And the second argument could be applied to all agencies. Most enabling statutes provide for a special method of judicial review of the respective agency's decisions. A more realistic reason for excluding war and emergency agencies from the operation of the Act might be that, despite intentions and assertions to the contrary, the APA neither simplifies nor materially standardizes administrative procedures, but rather makes them often more cumbersome, and that therefore agencies destined to cope with emergency situations should be freed from its application. If such a reason existed, it was, of course, never made explicit.

The usefulness of Section 2(a) is further reduced by the fact that the absence of any agency from the amended list of exceptions does not necessarily indicate that the Act applies to its procedures. For example, civil service procedures are exempted from the rule making procedure of the APA by Section 4, first sentence; from the adjudicatory procedure of Section 5 , since that section applies only where hearings are required by statute $;^{110}$ and, at least in the opinion of the Civil Service Commission, from the publicity requirements under Section $3(\mathrm{a}) .111$

Subsection (b). This section purports to define "party."112 It constitutes a good example of what administrative lawmaking cannot accomplish. The Act provides in so many words that a party is a person or agency named or admitted

107. SEN. Doc. No. 248 , at 387.

108. Ibid.

109. The most recent statute adding another exemption to the list is $\$ 709$ of the Defense Production Act of 1950.

110. See note 90 supra.

111. According to official interpretation, the exception of APA $\S 3$, first sentence, which exempts from publication "any matter relating solely to the internal management of an agency," includes "not only intra-agency personnel but also government personnel generally," despite the fact that this section speaks of "internal" management, whereas $\$ 4$, first sentence, referred to in the text above, exempts "agency management or personnel" in general. Letter of the U. S. Civil Service Commission to this author, dated April 10, 1950, File CL:AK:bh; AtTy. Gen. MaN. at 18, 27.

112. It also defines "person," but no significant controversy exists here as to the meaning of that term. 
or entitled to be a party. ${ }^{113}$ This definition bypasses the one problem whose solution a naive optimist might have expected: the question as to who has standing in an administrative procedure. The APA simply refers to the existing law with its many conflicting answers. ${ }^{114}$ The same technique is employed, incidentally, in the judicial review section of the Act, which entitles him to court review who "suffers legal wrong," or is "adversely affected or aggrieved" by agency action.115 But here again "legal wrong" means wrong under "the law" -not necessarily the APA--and so does "adversely affected or aggrieved."116 I am fully aware that it is probably not possible to state who has and who has not standing before an agency or review court with the same clarity as do the laws of civil and criminal court procedure. But this, indeed, is the very point: that administrative procedure is not, or not yet, capable of true restatement, generalities in the APA notwithstanding.

Subsections (c) and $(d)$. Whereas subsection (b) is harmless albeit useless, the same cannot be said of subsections (c) and (d), which are devoted to defining "rule" and "rule making" on the one hand and "order" and "adjudication" on the other. The Act fails to draw a clear line, or indeed any line at that, between the two categories of norms. From the legislative history as weil as the remarks of official and semi-official commentators it appears that the definitions are based on the belief (1) that there exists a "fundamental distinction" between rule making and adjudications ;117 and (2) that the Act not only makes this clear but also prescribes "radically different procedures" for either type of administrative procedure. ${ }^{118}$ Unfortunately, none of these assumptions are tenable.

(1) The difference between the various kinds of norms, including laws, regulations, and decisions, is gradual and not categorical. Statutes are often, but not inevitably, of wide application. Regulations usually-but again not necessarily-apply to more limited groups of persons or situations. Decisions, in

113. "Party" includes "any person or agency named or admitted as a party, or properly seeking and entitled as of right to be admitted as a party ..." And see SEN. Doc. No. 248 , at 196-7, 253.

114. For some of the problems involved see Davis, Standing to Challenge and Enforce Administrative Action, 49 Col. L. Rev. 759 (1949); Gellmorn, Administratrve LAw 400-428 (1947), quoting well-selected cases.

115. APA $\$ 10(a)$.

116. Cf. the discussion in SEN. Doc. No. 248, at 308-10.

117. Atty. Gen. Man. at 7; Rep. Atty. Gen. Com. Ad. Proc. 1, 2, 5 (1941); Sen. Doc. No. 248. at 254, 355 But see notes 135-6 infra.

118. Atry. Gen. Man. at 12-16; Sen. Doc. No. 248, at 251, 254, 355; McFarland, Amalysis of the Federal Administrative Procedure Act in The Federal Adannistrative Procedure Act and the Administrative Agencies 24 (Warren ed. 1947). But see Reich, Rule Making Under the Administrative Procedure Act in id. at 492-5, 510-14; Schwartz, supra note 103, at 67; Ginnane, "Rule Making," "Adjudication," and Exemptions Undcr the Administrative Procedure Act, 95 U. of PA. L. REv. 621 624-7 1947; Note, 56 YALE L. J. 670, 678-81 (1947). 
turn, are usually immediately applicable to but one or two parties.119 Yet a decree in the bankruptcy proceedings of a giant corporation may affect hundreds of thousands of creditors and shareholders. A generally worded transportation regulation, on the other hand, may in fact address itself to the only bus line in the state. Still less fruitful must be any attempt to recognize laws and regulations by their future applicability and decisions by their supposed reference to the past. For decisions are norms, in that they establish a legal duty or, which is the same thing, command somebody to do or refrain from doing something. Hence, they must logically "refer" to the future just as much as regulations. This is abundantly clear whenever such equity decrees as for a divorce, alimony, the abatement of a nuisance, or the cancelation of a deed, are involved. Even a money judgment is prospective, for while it implicitly repeats that there has existed A's duty to pay B, it establishes A's duty anew, which is now a duty under the judgment rather than under the contract between $A$ and $B$. There is no categorical difference between such a judgment and a regulation that "carries out" the provisions of a statute. Nor can an essential criterion be established by saying that only a decision is based on facts in the past. The judge decides on facts, as he sees them, that have occurred in the past, and so does the lawmaker. It is almost axiomatic to say that the making of a new law (or regulation) presupposes the existence of a "mischief," 120 that is, of a set of pre-existing facts that the lawgiver desires to do away with.

As long as laws are made by legislatures alone, the difference could be drawn quite easily from a purely mechanical, jurisdictional point of view: whatever the legislature enacts is a statute even though it be a so-called private act, which is substantially nothing but an individual decision emanating from the legislature. Conversely, only what the legislature does could be "laws" under this approach. Nowadays, however, general norms are often made by the same organ that is also authorized to render individual decisions. These general normsregulations-can be readily distinguished from statutes: the latter are made by the legislature, the former by agencies. But how is one to distinguish the regulations from the decisions that emanate from the same agency? As the distinction cannot be categorical, we must satisfy ourselves with a few quantitative criteria. ${ }^{121}$ Regulations may be said to differ from orders in that the former lay down rules for a group of people whose number is more or less indefinite and whose members are interchangeable. A food standards regulation is addressed to an indefinite number of food producers, however small though their number may actually be; and it is addressed to members of the group who were not in

119. Kersen, General Theory of Law and State 123-46 (1946); Note, 56 Yale L. J. $670,678-9$ (1947).

120. See Lord Coke's often-quoted reasoning in Heydon's Case, 3 Co. Rep. 7a, 7b, 76 Eng. Rep. 637, 638 (1584).

121. Fuchs, Procedure in Administrative Rule-Making, 52 HARv. L. REv. 259, 263-5 (1938) ; KELSEN, op. cit. supra note 119; Ginnane, supra note 118 . And see Philadelphia Co. v. SEC, 175 F. $2 d 808$ (D.C. Cir. 1948), noted in 34 MrNs. L. Rev. 464 (1950), vacated an motion of both parties, 337 U.S. 901 (1949). 
it when the regulation was made. An order, on the other hand, is addressed to and directs named individuals to do something, though their number may be great and they may receive notice by publication rather than through the mails. Orders, moreover, are usually arrived at upon motion of a party, ${ }^{122}$ whereas regulations are often promulgated ex motu proprio of the agency.

(2) The makers of the APA, far from improving upon these tentative criteria, have rather destroyed them. The trouble with the mutually exclusive definitions of Sections 2 (c) and (d) is that now "any action fits both definitions." 123 Thus a NLRB cease and desist order is injunctive and final, ${ }^{124}$ but at the same time it interprets law and is of particular applicability and future effect. ${ }^{125} \mathrm{~A}$ food standards regulation is unquestionably the final disposition, declaratory in form, of an agency, ${ }^{126}$ while it is at the same time a "statement" of general applicability and future effect designed to implement, interpret and prescribe law. ${ }^{127}$ In other words, the two definitions are worthless as far as the attempt of delineating regulations from orders goes. By defining rules as being of either general or particular applicability the lawmaker has included in what could be a workable description of regulations precisely the element that generally makes a norm a non-regulation, namely, an individual decision or order. ${ }^{128}$ The courts, so far, seem to have either ignored the definitions of (c) and (d) ${ }^{129}$ or politely mentioned them without using them. ${ }^{130}$

Furthermore, we note that the definition of subsection (c) includes in the term "rule" something not commonly conceived as law, viz., policy statements.

122. There are exceptions even in judicial law, such as disbarment proceedings, and administrative decisions are not infrequently arrived at in an inquisitory manner.

123. Note, 56 YALE L. J. 670, 680 (1947). The manner in which APA $\$ 2$ (c) and (d) attempt to distinguish between regulations and orders can be traced to Prentis v. Atlantic Coast Line, 211 U.S. 210, 226 (1910). For the case then at bar the reasoning was tenable, but in subsequent opinions the Court has not succeeded in consistently applying the criteria. Compare Assigned Car Cases, 274 U.S. 564, 583 (1927) with Terminal R. R. Assn. v. United States, 226 U.S. 17, 30 (1924), and Morgan v. United States. 298 U.S. 468, 480 (1936) with Ohio Valley Water Co. v. Ben Avon Borough, 253 U.S. 287, 289 (1920). And see Willapoint Oysters, Inc. v. Ewing, 174 F. 2d 676, 692-4 (9th Cir. 1949), cert. denied, 338 U.S. 860 (1949); Philadelphia Co., supra note 121.

124. APA $\$ 2$ (d).

125. $\$ 2(\mathrm{c})$.

126. $\$ 2$ (d).

127. $\$ 2$ (c). And see Willapoint Oysters, stipra note 123.

128. The inclusion of "rules of 'particular' applicability" was done by the House Judiciary Committee "in order to avoid controversy (!) and assure coverage of rule making to named persons." SEN. Doc. No. 248, at 283. In other words, to make sure that the term covers everything else besides rules! Cf. the discussion in Reich, supra note 118, at $510-14$.

129. E.g., the Philalelphia Co. case, supra note 121; Halstead v. SEC., 182 F. $2 d 660$ (D.C. Cir. 1950).

130. See, e.g., Arrow Airways, Inc. v. CAB, 182 F. 2d 705 (D.C. Cir. 1950) ; United Gas Pipe Line Co. v. FPC. 181 F. 2d 796 (D.C. Cir. 1950) ; Willapoint Oysters, supra note 123. 
The somewhat revolutionary character of this inclusion is diminished by the fact that the Act's rule making procedure does not apply to interpretative rules and general statements of policy. ${ }^{131}$ The public information provisions of Section 3, however, do expressly apply to "statements of general policy or interpretations formulated and adopted by the agency for the guidance of the public." In other words, an agency need not follow any particular procedure in arriving at and formulating a policy; but the policy, or rather its formulation, must be published in the Federal Register. This means that the Register must carry items that, while falling in the category of "rules" as set forth in Section 2 (c), are nevertheless not law in the sense of a binding norm. A regulation in the customary sense is binding because its promulgation is authorized in the enabling statute. It is, so to speak, a part of the statute. A mere policy statement, on the other hand, is as such not binding and consequently needs no authorization from a norm of a higher legal hierarchy. ${ }^{132}$ It merely announces how the agency intends to interpret the law. Such an announcement may be express or implied; it may follow from the agency's conduct or it may be deduced from press releases or newspaper interviews. Thus the NLRB last year announced the policy, which it has since followed, of declining to take jurisdiction in cases involving enterprises of mere local importance. ${ }^{133}$ According to the language of Sections 2 (c) and 3 (a), this policy announcement, or any policy formulation that amounts to a "statement," should be published in the Register despite the fact that the NLRB is not a rule making agency. But as there is nothing to prevent an agency from following a policy though unpublished, the law is not enforceable. Only rule making agencies have followed it, and those only to a limited extent. ${ }^{134}$

Subsections (e) through ( $g$ ). Subsections (e) and (f), defining "license," "licensing," "sanction," and "relief," may be passed over quickly. It remains to be seen whether a terminology that makes "license" a synonym of any permission is workable. ${ }^{135}$ The principal error is one of omission. The Act has not attempted to streamline the involved and altogether neglected legal machinery by which administrative decisions are "enforced," - that is, not merely sanc-

131. APA $\$ 4$ (a).

132. Even as a statute derives its force or, which is the same, validity, from the Constitution. On the hierarchy of norms see Kersen, General Theory of Law and State 123-61 (1945).

133. NLRB Press Release (R-303) of April 6, 1950. The main aspect of the release is a discussion of the Board's conflicts with its General Counsel.

134. See Reich, supra note 118, at 519-21; Dwan, The Federal Adninistrative Procedure Act and the Burean of Internal Revemue in The Federal Administratrve Procedure Act and the Administratrve Agencies 144-56, 164-8 (Warren ed. 1947).

135. For a discussion of some of the problems see Foster, Application of the Administrative Procedure Act to the Statutes Administered by the Securities and Exchange Commission in $i d$. at $213,225-37,251-2$. 
tioned by a review court but translated into actual fact, such as though contempt procedure. ${ }^{136}$

Subsection (g), finally, defines both "agency action" and "agency proceeding." The former term is used only in Section 10, pertaining to judicial review, and should properly have been defined there. The definition is not very useful in that it fails, again, to make clear the one important thing that ought to have been answered: against what acts does judicial review lie.

The other term ("agency proceeding") defined in subsection (g) does occur, but in Section 6(a), where its meaning is clear beyond doubt. This definition is therefore a useless superfluity.

136. The necessity of enforcing orders through contempt procedure has delayed final enforcement of some cases by several years. Parker, Contempt Proceditre in the Enforcement of Administrative Orders, 40 ILL. L. Rev. 344 (1946). 